\title{
Role of Educational attainment in Married Women's Entry into and Escape from Labor Force in Pakistan
}

\author{
${ }^{\mathrm{a}}$ Sidra Iqbal, ${ }^{\mathrm{b}}$ Hina Ali, ${ }^{\mathrm{c}}$ Fouzia Yasmin, ${ }^{\mathrm{d}}$ Maryyam Bint e Ajaz \\ a Lecturer, School of Economics, Bahaddin Zakariya University, Multan, Pakistan \\ Email: sidrach@bzu.edu.pk \\ ${ }^{\mathrm{b}}$ Assistant professor, Department of Economics, The Women University Multan, Pakistan \\ Email: hinaali@wum.edu.pk \\ ${ }^{\mathrm{c}}$ Lecturer, Department of Economics, University of Sahiwal, Pakistan \\ Email: Fouziayasmin@uosahiwal.edu.pk \\ ${ }^{\mathrm{d}}$ Lecturer, Department of Economics, University of Poonch, RawalaKot Azad Jamu Kashmir, Pakistan \\ Email: Maryamajaz@yahoo.com
}

\begin{tabular}{ll}
\hline ARTICLE DETAILS & ABSTRACT \\
\hline History: & The current analysis aims to establish a disaggregated impact of various \\
Accepted 20 April 2021 & stages of education on married women's labor supply, for which \\
Available Online June 2021 & responses on various socio-economic determinants of labor supply have \\
& been recorded from 834 females from District Sahiwal. Binomial Logistic \\
& Regression analysis concluded that education is generally the most \\
Keywords: & significant factor of female labor supply. A higher likelihood has been \\
Age, Female Labor Supply, & observed between educated females and a lower probability for non- \\
Education, Marital Status & educated ones to fall into the active labor force. However, a higher level \\
JEL Classification: & of assets ensures a lower probability of falling into the workforce, \\
A20, A29, Jo8 & furthermore, age, marital status, presence of children, and family setup \\
& corroborate female labor supply with a positive impact. Efforts need to \\
be made to transform a woman's role from an "income shielding" to an \\
"income-generating" role by providing education. Female economic \\
contribution and empowerment are influential tools to uplift the living \\
standard of the household level.
\end{tabular}

(C) 2021 The authors. Published by SPCRD Global Publishing. This is an open access article under the Creative Commons AttributionNonCommercial 4.0

Corresponding author's email address: hinaali@wum.edu.pk

\section{Introduction}

Females participate in the developmental process of an economy; nevertheless, their contribution to the labor market is often inadequate. Recent decades showed that there has been a significant reduction in gender disparity in developed and developing countries; however, the remuneration of females is less than males for performing the same work. Employment in South Asia is extremely unbalanced insofar as females are concerned when we look at the educational indicators in the region (Nasir et al., 2021). The main emphasis of this research article paper is to access the contribution of education concerning female labor supply decisions, in addition, it further enhances the 
socio-economic wellbeing of the household and the entire economy (Klasen \& Lamanna, 2009). Furthermore, the provision of education and employment enhances economic growth. However, the question needs to be addressed about the determinants of female working decisions broader spectrum.

According to the National Institute of Population Studies, the estimated population of Pakistan is 211.17 million in 2019. Hence, the working-age population has been estimated at 65.5 percent, consequently, Government is focusing on employment for females by providing education and skill development (Pakistan Economic Survey, 2020) as this the only way through which the fruits of growth can be disseminated to the underprivileged segment of the society. The economic indicators in Pakistan claim growth in GDP, an increase in education, and returns to education, amongst all these positive economic developments, women's labor supply continue to decline in Pakistan. As it is argued that the rate of female labor supply is lowest in South Asia (Anderson et al., 2017). This paradoxical situation of female working decisions in the phase of economic growth raises the need to investigate the behavior of LFPR at the micro-level with innovative datasets and estimation techniques (Sebastian, 2020). An ample of studies illustrates a low level of female labor supply in recent years and argues that the apprehension of the full economic potential of females can boost the inclusive growth and the wellbeing of a household (Mehrotra \& Sinha, 2017).

It has been found that women's access to education and economic participation reduces the risk of poverty in the home (Kabeer 2012); their employment is a key driver of economic growth in India (Klasen, 2019). Klaassen and Peters 2012) and enhances domestic economic well-being (Martin \& Roberts, 1984). Its impact is particularly important in poor households where women are not the sole donors or where other family members earn less (Morris 1990). However, because of their traditional "care" jobs, women chose part-time jobs. This also reduces their contribution to family income due to their low income (Smith et al. 2002). The potential impact of women's employment on the economic well-being of their families is based on three key factors (Stier \& Lewin, 2002). In addition, employment in other industries will not help the poor (Khera \& Nayak, 2009). It has also been observed that rural women (compared to rural men) are less educated and have fewer job opportunities. Otherwise it may not work. They can enter the labor market to support the economic needs of the family, less experienced and less skilled than men of the army can be trapped in a low-wage cycle, moving from one low-paying job to another. the impact of poor female labor in reducing domestic poverty is small.

Females across all over the world have general constraints to become a part of the labor force. Owing to the socio-economic pattern, these restrictions are more obvious in the case of Pakistan, as mostly they are involved in unpaid activities without any job protection (Sarwar \& Abbasi, 2013). Family characteristics are very important in determining women's participation in the labor force. If the family system is nuclear, the household head is educated, less number of pre-school children, and financial constraints are here then more chances for females to enter the labor market (Shaheen et al., 2015).

\section{Literature Survey}

Faridi et al. (2009) investigated Social, Economic, and Demographic determinants of female participation through a field Survey in District Bahawalpur. By using the Binomial Logistic regression Model, the study has come up with that education of females is the most effective variable among all other variables e.g. age, educational status, marital status, family setup, household asset, region, and husband salaries. Furthermore, the presence of children creates a great hurdle to their work. 
Shaheen et al. (2011) have used the data of Punjab from the Multiple Indicator Cluster Survey (2007-08) to determine female labor force participation in Pakistan. Family size, household head education, family income, marital status, employment status, all different levels of education, and monthly income of women were taken as the variables of the study. The results of the Logit Model showed that urban areas, married females, only higher education, and large family size have a positive effect on FLFP.

Hafeez and Ahmad, (2002) indicated that household income and land ownership or homeownership decrease (about 6-7\%) female labor force participation (FLFP) in District Mandibahaudin. Results based on the Logit and Probit Model showed that lack of education is the major hurdle in the female working, especially from rural areas. Furthermore, women with a higher level of education participate more than low-level education. Age, family size, and husband's education also positively affect FLFP. (Tansel, 2002) explored the U-shaped relationship between economic development and female labor force participation across 67 provinces of Turkey. Regional differences among provinces are the main reasons to determine female participation in the labor force along with higher education.

Olivetti (2013) investigated a consistent U-shaped relationship between GDP and FLFP in America. He takes the data of 16 developed European countries from 1890 to 2005. Both within and across the countries, in the long-run process of structural development reallocates the share of labor among different sectors of the economy. When an economy transforms from agriculture to manufacture and services, it explains the downward portion of U-shaped FLFP. (Mujahid \& Zafar, 2011) empirically tested and proved the long-run U-shaped relationship between economic development and FLFP in Pakistan. By employing ARDL-technique, the study concluded that Real GDP per Capita explains 95.36\% FLFP.

Faridi et al. (2009) have made an effort to calculate FLFP across different levels of education. They get evidence by collecting primary data from 164 females of Bahawalpur. Education above the middle level has a pronounced effect on female activity in the job market. The study concludes that professional and vocational education empowers women. Bibi \& Afzal (2012) identified financial reasons to work or not. If there is high inflation in the economy then the female has to choose paid work. They concluded that family attitude toward working activities, family setup, family status, husband attitude toward working activities, husband education, husband status of the job, personal status consciousness, wage rate, and job satisfaction determine females to enter in the job market. Shaheen et al. (2015) determined various factors of female employment status by collecting data through a field survey of 402 females. Results of the multinominal logistic regression model concluded that age, education, marital status, have a positive impact on female paid work. The presence of assets and household size is negatively related to female employment.

Aboohamidi \& Chidmi (2013) also concluded that good education policies and urbanization process arouses females to take an active part in the labor market. Trade policies have no such significant relation to FLFP. (Tanaka et al., 2020) concluded that in Bangladesh labor force participation (LFP) rates are observed stagnant for females notwithstanding progress toward gender equality in education in rural areas. The benefit of education investment in females in rural areas has a greater impact on their working by applying a fuzzy regression discontinuity design. They have found a significant impact of female education on their labor force. 


\section{Data and Methodology}

\subsection{Data sources}

To check the role of education on female labor supply district Multan was chosen as the study area. Primary data was collected from female respondents belonging to the age group 16-65 years. The researcher has recorded information from both rural and urban respondents about their socioeconomic and demographic status that has a critical role in female labor supply.

\subsection{Methodological Design}

This empirical research has been descriptively as well as econometrically. Descriptive analysis was presented as mean, variance, standard deviation, kurtosis, jerque-bera, and correlation coefficients among the variables. The second stage of the analysis utilized the binary logistic regression technique for estimation of parameters that shows the impact of female educational attainment on their working decision.

Many socio-economic and demographic factors affect a female to be the inactive workforce. The general labor supply model is as follows,

$$
Y_{i}=f\left(X_{1}, X_{2}, X_{3}, \ldots \ldots \ldots \ldots, X_{n}\right)
$$

$Y_{i}=$ decision to be inactive workforce

$X_{i}=$ other control variables.

The variable may take two values either 1 or o. If a female is participating in a paid job the variable assumes 1 and if she is not doing a paid job the value is o. Now we move towards the general form of the model that is,

$$
W \dot{L} S_{\imath}=\beta L_{i}+\varepsilon_{i}
$$

Where,

"WLS $\dot{S}_{l}$ " is a latent variable that denotes women labor supply, "Li $L_{i}$ is a vector of different factors that affect the female labor supply decision, " $\beta$ " is a vector coefficient to be measured and " $\varepsilon_{i}$ "is the error term.

Female would be employed if:

$$
\begin{aligned}
& W L S_{i}=\beta L_{i}+\varepsilon_{i}>\mathrm{o} \\
& W L S_{i}=\beta L_{i}+\varepsilon_{i} \leq \mathrm{o}
\end{aligned}
$$

The female has a paid job. $L_{i}$ Represent different demographic and economic factors that determine employment. $W L S$ is latent that assumes the values of $(0,1), W L S=1$ if $W L S_{i}>0$ and $W L S=0$ Otherwise. In the current empirical analysis $W L S_{i}$ is the binary dependant variable. The logit regression technique was employed here because the dependent variables in our analysis are binary. The Logit regression assumes the following cumulative probability density function.

$$
W L S_{i}=\frac{1}{1-e^{-\beta L_{i}}}
$$

Where $W L S$ is the probability of female participation in labor supply. " $e$ " Is the exponential value. " $\beta$ " is the vector of parameters and $\mathrm{Li}$ is the column of the explanatory variables. The natural log 
of the odds ratio of employment $\ln \left(\frac{W L S_{i}}{1-W L S}\right)$ can be expressed as a linear function of explanatory variables,

$$
\ln \left(\frac{W L S_{i}}{1-W L S}\right)=\beta L_{i}
$$

Now we have the estimated parameters are the Logit model register the effect on the log odds of a little change in the independent variables.

\section{Table 1: Variables Description}

\begin{tabular}{|c|c|}
\hline Variable & Description \\
\hline female labor supply (WLS) & $\begin{array}{l}=1 \text { and } \mathrm{o} \text {, female is doing paid work and female is not doing } \\
\text { paid work respectively }\end{array}$ \\
\hline Age (AGEY) & age of female in years \\
\hline completed years of education (EDUC) & $=1$ and $\mathrm{o}$, if the female is educated and illiterate respectively \\
\hline $\begin{array}{l}\text { The primary level of education } \\
\text { (EDUP) }\end{array}$ & $\begin{array}{l}=1 \text { and } \mathrm{o} \text {, female have primary education certificate and } \\
\text { other respectively }\end{array}$ \\
\hline $\begin{array}{l}\text { The middle level of education } \\
\text { (EDUM) }\end{array}$ & $\begin{array}{l}=1 \text { and } \mathrm{o} \text {, female have middle education certificate and other } \\
\text { respectively }\end{array}$ \\
\hline Secondary level of education (EDUS) & $\begin{array}{l}=1 \text { and } \mathrm{o} \text {, female have metric education certificate and } \\
\text { other respectively }\end{array}$ \\
\hline $\begin{array}{l}\text { Intermediate level of education } \\
\text { (EDUI) }\end{array}$ & $\begin{array}{l}=1 \text { and } \mathrm{o} \text {, female have intermediate education certificate and } \\
\text { other respectively }\end{array}$ \\
\hline Bachelor level of education (EDUB) & $\begin{array}{l}=1 \text { and } \mathrm{o} \text {, female have bachelor's degree and other } \\
\text { respectively }\end{array}$ \\
\hline Masters level of education (EDUM) & $\begin{array}{l}=1 \text { and } \mathrm{o} \text {, female have masters or above degree and other } \\
\text { respectively }\end{array}$ \\
\hline Marital Status (MRTS) & $=1$ and $\mathrm{o}$, if a female is married and unmarried respectively \\
\hline No. Of children (NCHL) & Total no. of children \\
\hline Assets (ASST) & $\begin{array}{l}=1 \text { and } \mathrm{o} \text {, female have assets and not have assets } \\
\text { respectively }\end{array}$ \\
\hline Major Disease (MIDS) & $\begin{array}{l}=1 \text { and } 0 \text {, female have a major disease and healthy } \\
\text { respectively }\end{array}$ \\
\hline FAMILY SETUP (FSTP) & $\begin{array}{l}=1 \text { and } \mathrm{o} \text {, if female lives with joint family and nuclear } \\
\text { family respectively }\end{array}$ \\
\hline Area Of Residence (RISD) & $=1$ and $\mathrm{o}$, if female lives urban and rural area respectively \\
\hline Married and educated (MTS_EDU) & $\begin{array}{l}=1 \text { and } \mathrm{o} \text {, female is literate and married and illiterate and } \\
\text { married respectively }\end{array}$ \\
\hline Numbers of Dependants (NDPN) & Total no. of dependents in a house \\
\hline Numbers of working (TWRK) & Total working people in a house \\
\hline
\end{tabular}

\subsection{Empirical Model Specification}

Empirical models for the analysis are formulated as follows.

\subsubsection{Impact of Completed Years of Education on Female Labor Supply}

To observe the impact of completed years of education on female labor supply we have specified the model as follows 
$W L S=f(A G E Y, E D U C, M R T S, N C H L, A S S T, M D I S, F S T P----e q u a t i o n$ no. 1

$$
\begin{array}{r}
W L S=\beta 0+\beta 1(A G E Y)+\beta 2(E D U C)+\beta 3(M R T S)+\beta 4(A S S T)+\beta 5(M I D S)+ \\
\beta 6(F S T P)+\varepsilon 1-
\end{array}
$$

Completed years of education were modeled with the Age, education in years, marital status, assets presence, Health, and Family set up as the control variables.

\subsubsection{Impact of Educated Married Female on Female Labor Supply}

The impact of educated married females was observed along with the other control variables. The model is formulated as follows:

$W L S=f\left(A G E Y, E D U C, M R T S, N C H L, A S S T, M D I S, F S T P R E S D, M T S \_E D U, N D P N,\right)$-Equation no. 3

$$
\begin{aligned}
& E M P L=\gamma 0+\gamma 1(A G E Y)+\gamma 2(E D U C)+\gamma 3(M R T S)+\gamma 4(A S S T)+\gamma 5(M I D S)+ \\
& \gamma 6(F S T P)+\gamma 7(R E S D)+\gamma 8\left(M T S \_E D U\right)+\gamma 9(N D P N)+\varepsilon 2------ \text { Equation no. } 4
\end{aligned}
$$

\subsubsection{Impact of Disaggregated Education Levels on Female Labor Supply}

The role of education is analyzed in the following model at each level with different other control variables.

$$
W L S=f(A G E Y, E D U P, E D U M, E D U S, E D U I, E D U B, E D U H, M R T S, N C H L, A S S T, M I D S
$$

, FSTP RESD, MTS_EDU, NDPN,TWRK)---------------------------------------Equation no. 5

$W L S=\delta 0+\delta 1(A G E Y)+\delta 2(E D U P)+\delta 3(E D U M)+\delta 4(E D U S)+\delta 5(E D U I)+\delta 6(E D U B)+$ $\delta 7(E D U H)+\delta 8(M R T S)+\delta 9(N C H L)+\delta 10(A S S T)+\delta 11(M I D S)+\delta 12(F S T P)+$ $\delta 13(R E S D)+\delta 14\left(M T S \_E D U\right)+\delta 15(N D P N)+\delta 16(T W R K)+\varepsilon 3---$ equation no. 6

\section{Empirical Results and Discussion}

\subsection{Correlation Analysis}

Pair-wise correlation coefficients are presented in the table below. Analysis shows that no variable is highly collinear with each other confirming the absence of high multicollinearity. 
TABLE 1: CORRELATION ANALYSIS

\begin{tabular}{|l|l|l|l|l|l|l|l|l|l|l|l|l|l|l|l|l|}
\hline & AGY & EDP & EDM & EDS & EDI & EDH & EDB & MTS & NCH & AST & MDS & FST & RSD & $\begin{array}{l}\text { MTS } \\
\text { EDU }\end{array}$ & NDP & TWR \\
\hline AGEY & 1.00 & 0.08 & 0.07 & -0.02 & -0.11 & -0.10 & -0.18 & 0.63 & 0.69 & -0.28 & -0.09 & -0.26 & -0.05 & 0.36 & 0.23 & 0.01 \\
\hline EDUP & & 1.00 & -0.07 & -0.12 & -0.07 & -0.11 & -0.11 & 0.08 & 0.11 & -0.16 & -0.05 & -0.11 & 0.00 & 0.13 & 0.06 & -0.01 \\
\hline EDUM & & & 1.00 & -0.15 & -0.06 & -0.13 & -0.13 & 0.11 & 0.09 & -0.06 & 0.06 & -0.02 & 0.07 & 0.17 & 0.03 & -0.10 \\
\hline EDUS & & & & 1.00 & -0.16 & -0.24 & -0.24 & 0.07 & 0.04 & -0.02 & -0.01 & -0.01 & -0.01 & 0.18 & 0.07 & -0.01 \\
\hline EDUI & & & & & 1.00 & -0.14 & -0.14 & -0.05 & -0.06 & 0.05 & 0.01 & 0.09 & 0.10 & 0.02 & -0.01 & -0.07 \\
\hline EDUH & & & & & & 1.00 & -0.21 & -0.10 & -0.21 & 0.12 & -0.07 & 0.03 & 0.10 & 0.01 & -0.12 & 0.05 \\
\hline EDUB & & & & & & & 1.00 & -0.21 & -0.24 & 0.13 & -0.02 & 0.13 & -0.05 & -0.09 & -0.10 & 0.12 \\
\hline MRTS & & & & & & & & 1.00 & 0.64 & -0.35 & -0.15 & -0.38 & 0.08 & 0.78 & 0.43 & -0.17 \\
\hline NCHL & & & & & & & & & 1.00 & -0.33 & -0.13 & -0.29 & -0.03 & 0.39 & 0.58 & -0.08 \\
\hline ASST & & & & & & & & & & 1.00 & 0.19 & 0.13 & 0.10 & -0.29 & -0.23 & -0.04 \\
\hline MIDS & & & & & & & & & & 1.00 & 0.15 & 0.00 & -0.16 & -0.06 & -0.02 \\
\hline FSTP & & & & & & & & & & & & 1.00 & -0.04 & -0.32 & 0.01 & 0.37 \\
\hline RISD & & & & & & & & & & & & & 1.00 & 0.10 & 0.06 & -0.06 \\
\hline MTS_EDU & & & & & & & & & & & & & & 1.00 & 0.32 & -0.16 \\
\hline NDPN & & & & & & & & & & & & & & & & \\
\hline TWRK & & & & & & & & & & & & & & & & \\
\hline
\end{tabular}




\subsection{Descriptive Analysis}

Descriptive statistics of the variables observed are stated in the following table. That explains the mean, std.dev, Skewness, kurtosis of the variables.

Table 2: Summary Statistics

\begin{tabular}{|l|l|l|l|l|}
\hline & Mean & Std. Dev. & Skewness & Kurtosis \\
\hline AGEY & 33.5682 & 10.1510 & 0.6113 & 2.7549 \\
\hline EDUP & 0.1365 & 0.5848 & 12.2983 & 202.3110 \\
\hline EDUM & 0.0769 & 0.2668 & 3.1754 & 11.0833 \\
\hline EDUS & 0.2159 & 0.4119 & 1.3811 & 2.9075 \\
\hline EDUH & 0.0893 & 0.2856 & 2.8797 & 9.2925 \\
\hline EDUB & 0.1737 & 0.3793 & 1.7226 & 3.9674 \\
\hline MRTS & 0.1687 & 0.3750 & 1.7690 & 4.1295 \\
\hline NCHL & 0.6873 & 0.4642 & -0.8083 & 1.6533 \\
\hline ASST & 2.0968 & 2.1038 & 0.7613 & 3.0774 \\
\hline MIDS & 0.6749 & 0.4690 & -0.7470 & 1.5580 \\
\hline FSTP & 0.2978 & 0.4578 & 0.8845 & 1.7824 \\
\hline RISD & 0.3846 & 0.4871 & 0.4743 & 1.2250 \\
\hline MTS_EDU & 0.3672 & 0.4827 & 0.5508 & 1.3034 \\
\hline NDPN & 0.5732 & 0.4952 & -0.2960 & 1.0876 \\
\hline TWRK & 1.7395 & 1.6449 & 0.6393 & 2.5266 \\
\hline
\end{tabular}

Source: Author's own Estimations

\subsection{Estimate of Binominal logit Regression}

Binominal logistic regression predicts when a woman is in the labor force. Considering female labor force participation we estimate a binomial logit model. A researcher has used a two-tailed test of significance or Z statistics for determining the acceptance or rejection of our null hypothesis.

TABLE 3: BINOMIAL LOGISTIC REGRESSION ESTIMATES: IMPACT OF COMPLETED YEARS OF EDUCATION ON FEMALE LABOR SUPPLY

\begin{tabular}{|l|l|l|}
\hline Variable & Coefficient & z-Statistic \\
\hline C & -2.104867 & $-2.478131^{* * *}$ \\
\hline AGEY & 0.084557 & $4.098720^{* * *}$ \\
\hline EDUC & 0.162666 & $4.913131^{* * *}$ \\
\hline MRTS & 1.178928 & $2.662177^{* * *}$ \\
\hline NCHN & 0.033530 & 0.244650 \\
\hline ASST & -2.971754 & $-7.189019^{* * *}$ \\
\hline MIDS & -1.895062 & $-5.691944^{* * *}$ \\
\hline FSTP & 0.519660 & 1.343178 \\
\hline Log likelihood & \\
\hline Probability $($ LR stat) & 0.000000 & \\
\hline LR statistic $(8 d f)$ & \\
\hline McFadden $R-$ squared & \\
\hline
\end{tabular}

Source: Author's own Estimations

Note: Significant at $1 \%=* * *$, Significant at $5 \%=* *$, Significant at $10 \%=*$ 
Table 4: Binomial Logistic Regression Estimates: Impact of educated married female on female labor supply

\begin{tabular}{|l|l|l|}
\hline Variable & Coefficient & z-Statistic \\
\hline C & -2.361382 & $-2.687132^{* * *}$ \\
\hline AGEY & 0.063081 & $2.723334^{* * *}$ \\
\hline EDUC & 0.154161 & $3.413410^{* * *}$ \\
\hline MRTS & 1.392373 & 1.689648 \\
\hline NCHL & 0.131422 & 0.917833 \\
\hline ASST & -2.992881 & $-7.074681^{* * *}$ \\
\hline MIDS & -1.906554 & $-5.631847^{* * *}$ \\
\hline FSTP & 0.310357 & 0.885964 \\
\hline RISD & 0.086204 & 0.299756 \\
\hline MTS_EDU & 0.182330 & 0.280837 \\
\hline NDPN & -0.209586 & -1.647610 \\
\hline TWRK & 0.301668 & $2.126338^{* *}$ \\
\hline Log likelihood - 159.6560 & \\
\hline Probability $($ LR stat $)$ & 0.000000 & \\
\hline LR statistic $(11$ df $)$ & \\
\hline McFadden $R-$ squared 0.425797 & \\
\hline Source:Authors ownestimations. & \\
\hline
\end{tabular}

Source: Author's own estimations.

Note: Significant at $1 \%=* * *$, Significant at $5 \%=* *$, Significant at $10 \%=*$

Table 5: Binomial Logistic Regression Estimates: Impact of disaggregated education levels on female labor supply

\begin{tabular}{|l|l|l|}
\hline Variable & Coefficient & z-Statistic \\
\hline AGEY & -1.396683 & -1.615718 \\
\hline EDUP & 0.061828 & $2.612086^{* * *}$ \\
\hline EDUM & -0.171029 & -0.590278 \\
\hline EDUS & 0.292346 & 0.396281 \\
\hline EDUI & 0.546694 & 0.895331 \\
\hline EDUB & 1.341512 & $1.775829^{*}$ \\
\hline EDUH & 1.114701 & $1.707029^{*}$ \\
\hline MRTS & 1.806142 & $2.791586^{* * *}$ \\
\hline NCHL & 0.587409 & 0.705114 \\
\hline ASST & 0.135423 & 0.927962 \\
\hline MIDS & -3.100989 & $-7.023295^{* * *}$ \\
\hline FSTP & -1.909612 & $-5.616288^{* * *}$ \\
\hline RISD & 0.297419 & 0.827190 \\
\hline MTS_EDU & 0.057180 & 0.193332 \\
\hline NDPN & 1.100364 & 1.587695 \\
\hline TWRK & -0.225811 & $-1.748246^{*}$ \\
\hline Log likelihood & 0.303539 & $2.1255^{* *}$ \\
\hline Probability (LR stat) -157.3991 & \\
\hline LR statistic $(11$ df $)$ & 0.000000 & \\
\hline McFadden $R-$ squared 239.7000 & & \\
\hline
\end{tabular}


Source: Author's own Estimations.

Note: Significant at $1 \%=* * *$, Significant at $5 \%=* *$, Significant at $10 \%=*$

The age of women is the most important determinant of women's participation in paid work. Age got a significant place among the determents of a woman in paid employment. The age coefficient illustrates that as a female gets older paid work is more important to her. The values are significant at $1 \%$. With the increase in age, a woman gets married so increase in the familial responsibilities by having more children she should be a part of the active labor force just to share the financial burden with her spouse. All the included models represent similar empirical findings. The level of education of women is the most important factor that forces a woman to participate in professional activities. With an increase in education, individuals turn out to be better equipped and more productive. Educational investment is a way of investing in human capital as it presents an explosive stream of returns in the late age (Backer, 1964).

Educational accomplishment is positively and significantly associated with economic outcomes in terms of employment and later on, it contributes to enhancing the overall economic growth of the country. Research has found the distinct impact of the different levels of education in the third model with the primary and middle education level has a positive but insignificant impact on women's employment decisions. Secondary education does not boost employment decisions at a greater rate than the other high of education. A strong positive impact on female paid participation in the labor market is observed with an insignificant slope coefficient. Intermediate education accumulates more human capital and has a constructive and significant role in employment decisions. This level of education has a considerable impact on employment decisions and some other income-generating activities. The initial level of the high level of education along with the more high level of education illustrates the direct strapping an important contact on women's contribution in the labor market. Extremely knowledgeable individuals have an additional approach to be a part of income-generating activities and be a part of the active labor force.

Marital status is directly associated with female employment. Married females have supplementary household tasks to accomplish along with sharing the financial burden while the other side of the picture; the unmarried are not interested in learning activities. Current research has found the same findings in all the empirical models. Females having children have a positive association for employment to earn some financial rewards. But the coefficient did not show any significant impact. Presence of assets negatively and significantly related to female labor force participation.

The presence of assets and the presence of major diseases restrict the probability that a female has a paid job. Restriction on entry into the labor force is imposed in the presence of the above-mentioned variables. Females living in joint families, females residing in urban areas increase, and the presence of more dependants in households push a female to take part in the labor force. the probability of being employed in comparison with the nuclear family system and the rural residential households.

\section{Conclusion and policy recommendations}

The research concluded that age and education had positive contact with female employment. Each additional year of schooling augments the probability of being an active individual in the labor force. It is concluded that intermediate education is necessary to have a paid employment and to enter the labor market As it was investigated that the low level of education is insignificant in determining the level of female employment. A high level of education increases the chances of employment. Marital status plays an important role in women's participation in the labor market. The presence of assets, the presence of major disease negatively interrelated to female employment. Family setup and the urban residence create women's employment opportunities. Research also accomplished the results a female must attain intermediate to higher education level to gain the explosive returns to their investment on education. Policymakers must consider the provision of higher education institutions to females. As It was investigated that there are fewer opportunities in the rural areas and the employer contribution from the rural population is low govt. must provide employment opportunities at the rural level. An institute of technical and vocational training should be created for the enhancement of the 
employment of women. To adjust the nonworking labor more labor-intensive industries should be installed. To improve the health status of workers health facilities should be provided a council level.

\section{References}

Aboohamidi, A., \& Chidmi, B. (2013). Female Labor Force Participation in Pakistan and Some MENA Countries (No. 1373-2016-109220).

Anderson, A., Loomba, P., Orajaka, I., Numfor, J., Saha, S., Janko, S., ... \& Larsen, R. (2017). Empowering smart communities: Electrification, education, and sustainable entrepreneurship in IEEE smart village initiatives. IEEE Electrification Magazine, 5(2), 6-16.

Bibi, A., \& Afzal, A. (2012). Determinants of Married Women Labor Force Participation in WahCantt: A Descriptive Analysis. Academic Research International, 2(1).

Faridi, M. Z., Chaudhry, I. S., \& Anwar, M. (2009). The Socio-Economic and Demographic Determinants of Women Work Participation in Pakistan: Evidence from Bahawalpur District. A Research Journal of South Asian Studies, 24(2), 351-367.

Faridi, M. Z., Malik, S., \& Basit, A. B. (2009). Impact of Education on Female Labour Force Participation in Pakistan: Empirical Evidence from Primary Data Analysis. Pakistan Journal of Social Sciences (PJSS), 29(1).

Hafeez, A., \& Ahmad, E. (2002). Factors determining the Labor Force Participation Decision of Educated Married Women in a District of Punjab. Pakistan Economic and Social Review, XL(1), 75-88.

Kabeer, N. (2012). Women's economic empowerment and inclusive growth: labour markets and enterprise development.

Khera, R., \& Nayak, N. (2009). Women Workers and perceptions of the National rural employment Guarantee act. Economic and Political Weekly, 49-57.

Klasen, S. (2019). What explains uneven female labor force participation levels and trends in developing countries?. The World Bank Research Observer, 34(2), 161-197.

Klasen, S., \& Lamanna, F. (2009). The impact of gender inequality in education and employment on economic growth: new evidence for a panel of countries. Feminist economics, 15(3), 91-132.

Martin, J., \& Roberts, C. (1984). Women and Employment. Report on the Department of Employment/OPCS Survey.

Mehrotra, S., \& Sinha, S. (2017). Explaining falling female employment during a high growth period. Economic \& Political Weekly, 52(39), 54-62.

Morris, L. (1990). The workings of the household: A US-UK comparison. Polity Press.

Mujahid, N., \& uz Zafar, N. (2012). Economic growth-female labour force participation nexus: an empirical evidence for Pakistan. The Pakistan Development Review, 565-585.

Nasir, H., Alam, S., \& Fatima, A. (2020). The Impact of Gender Inequality in Education on Females' Labor Force Participation: A Case of Some Cities of Pakistan. International Economics Studies, 5O(2), 1-16.

Nasir, N., Yasmin, F., \& Safdar, N. (2021). Employment Diversification Patterns in Pakistan: Empirical Assessment Revisited. Review of Economics and Development Studies, 7(1), 77-90.

Olivetti, C. (2014). 5. The Female Labor Force and Long-Run Development (pp. 161-204). University of Chicago Press.

Pagan, C., \& O'reilly, J. (1998). The value of an integrated comparative perspective. Part-time prospects: An international comparison of part-time work in Europe, North America and the Pacific Rim, 1.

Rani, U., \& Schmid, J. P. (2007). Household characteristics, employment and poverty in India. In 2nd IZA/World Bank conference on employment and development.

Sebastian, N. (2020). Entry into and Escape from Poverty: The Role of Female Labor Supply in Rural India. The Indian Journal of Labour Economics, 63(3), 719-740.

Shaheen, R., Shabir, G., Faridi, M. Z., \& Yasmin, F. (2015). Determinants of female employment status 
in Pakistan: A case of Sahiwal District. Pakistan Journal of Commerce and Social Sciences (PJCSS), 9(2), 418-437.

Shaheen, S., \& Awan, M. S. (2011). Female labor force participation in pakistan: a case of Punjab. Journal of Social and Development Sciences, 2(3), 104-110.

Smith, M., Fagan, C., \& Rubery, J. (2002). Where and why is part-time work growing in Europe?. In Part-time prospects (pp. 53-74). Routledge.

Stier, H., \& Lewin, A. C. (2002). Does women's employment reduce poverty? Evidence from Israel. Work, Employment and Society, 16(2), 211-230.

Tanaka, T., Takahashi, K., \& Ōtsuka, K. (2020). Increasing female education, stagnating female labor force participation, and gains from marriage: The case of rural Bangladesh (No. 19-34). National Graduate Institute for Policy Studies.

Tansel, A. (2002). Economic development and FLFP in Turkey: Time series evidence and cross province estimates. ERC Working paper in Economics 01/05. 